\title{
SISTEM MANAJEMEN ARSIP DI MTS AULIA CENDIKIA PALEMBANG
}

\author{
Nurlia Iswandi, Nabila Ainun Nazifah, Husnul Khotimah, Melta Anggraini, JJ. Okshi \\ Program Studi Ilmu Perpustakaan, Fakultas Adab dan Humaniora, UIN Raden Fatah \\ Palembang \\ nurlia315@gmail.com; nabilanazifah1998@gmail.com; \\ husnulkhotimahnyoman17@gmail.com; meltanggraini@yahoo.com; gaulocik@gmail.com
}

\begin{abstract}
Archives are proof of activities or activities within an organization or institution. Archives will always increase every day, and therefore must be managed properly so that when you find back it becomes easier. This convenience encourages the creation of a tool or technology that makes it easy for someone to manage archives that are not small in number. This is what is called an electronic archive. Electronic archives require a technology that can store records, such as computers and applications to manage them. Electronic archives emerged as a manifestation of the development of information technology and answers to the importance of managing archives in an institution, be it a government, education, library, company, etc. The purpose of this study is to find out how to manage archives, archive storage media, and how to retrieve archives at MTS Aulia Cendikia. The research method used is descriptive qualitative research method. The technique of data collection is done by observing directly and interviewing the records manager at MTS Aulia Cendikia. The results obtained are in MTS Aulia Cendikia still managing manually, where textual archives that come and go out are stored on shelfspecific shelves labeled with names to facilitate archival retrieval. Electronic archives in the form of student data are stored in the EMIS (Education Management Information System) application.
\end{abstract}

Keywords: Archives, Electronic Archives, Archival storage media, Archival management, archive retrieval

\section{Intisari}

Arsip merupakan tanda bukti adanya kegiatan atau aktifitas di dalam suatu organisasi atau lembaga. Arsip akan selalu bertambah setiap harinya, maka dari itu harus dikelola dengan baik agar saat menemukan kembali menjadi lebih mudah. Kemudahan inilah yang mendorong terciptanya sebuah alat atau teknologi yang memudahkan seseorang dalam mengelola arsip yang jumlahnya tidak sedikit. Hal inilah yang disebut arsip elektronik. Arsip elektronik membutuhkan sebuah teknologi yang dapat menyimpan arsip, seperti komputer dan aplikasi untuk mengelolanya. Arsip elektronik muncul sebagai wujud dari perkembangan teknologi informasi dan jawaban dari pentingnya mengelola arsip dalam sebuah lembaga baik itu lembaga pemerintahan, pendidikan, perpustakaan, perusahaan, dsb. Tujuan dari penelitian ini untuk mengetahui bagaimana pengelolaan arsip, media penyimpanan arsip, dan cara temu kembali arsip di MTS Aulia Cendikia. Metode penelitian yang digunakan yaitu metode penelitian kualitatif deskriptif. Teknik pengumpulan data dilakukan dengan observasi mengamati langsung dan wawancara kepada pengelola arsip di MTS Aulia Cendikia. Hasil yang didapatkan yaitu di MTS Aulia Cendikia masih mengelola secara manual, dimana arsip tekstual yang datang dan keluar disimpan di rak khusus rak yang diberi label nama untuk mempermudah temu kembali arsip. Arsip elekrronik berupa data - data siswa, disimpan di aplikasi EMIS (Education Management Information System).

Kata kunci: Arsip, Arsip Elektronik, Media penyimpanan arsip, Pengelolaan arsip, temu kembali arsip 


\section{PENDAHULUAN}

Setiap organisasi, baik itu profit maupun non profit sudah pasti dan selalu membutuhkan sebuah bukti atau rekaman dari setiap kegiatan yang dilakukanoleh lembaga atau organisasi tersebut sebagai alat bantu mengingat atau memori pribadi, untuk kepentingan administrasi, hukum, maupun kepentingan - kepentingan yang lain.Bukti atau rekaman dari setiap kegiatan tersebut dinamakan dengan arsip.

Arsip merupakan memori korporat bagi organisasi yang menciptakannya. Ia memberikan bukti bagi tindakan, keputusan dan komunikasi, serta merupakan bahan akuntabilitas dari instansi yang memilikinya. Arsip lebih dari sekadar berisi data karena arsip merupakan bukti dari tindakan dan keputusan (Rustam: 2014). Menurut Undang Undang Republik Indonesia No. 7 Tahun 1971Pasal 1 ayat (a) tentang Ketentuan - Ketentuan Pokok Kearsipan, menyebutkan bahwa arsip adalah naskah - naskah yang dibuat dan diterima oleh lembaga negara dan badan - badan pemerintahan dalam bentuk corak apa pun, baik dalam keadaan tunggal maupun berkelompok, dalam rangka pelaksanaan kegiatan pemerintah.

Sama hal nya dengan National Archives and Record Administration yang menyebutkan "An archives is a place where people can go to gather firsthand facts, data, and evidence from letters, reports, notes, memos, photographs, and other primary sources" maksudnya adalah arsip merupakan sebuah tempat dimana manusia bisa mendapatkan fakta, data, bukti dari surat, laporan, catatan, memo, foto, dan sumber-sumber primer lainnya yang terkait dengan organisasi atau lembaga pencipta arsip.

Seperti yang disebutkan diatas bahwa arsip adalah bukti dari surat, laporan, dsb dari sebuah organisasi. Jika organisasi itu beroperasi setiap harinya maka arsip akan terus bertambah per harinya. Arsip akan terus bertambah setiap harinya seiring dengan proses kegiatan organisasi. Maka dari itu diperlukan sebuah pengelolaan arsip yang baik agar disaat membutuhkan arsip akan lebih cepat dalam menemukan kembali arsip nya.

Menemukan kembali arsip yang diperlukan akan lebih mudah jika arsip dikelola dan disimpan dengan baik. Pengelolaan arsip ini bisa dilakukan secara manual dan secara elektronik. Pengelolaan secara elektronik lahir dari perkembangan teknologi, khususnya perkembangan teknologi komputer.

Seiring berkembangnya teknologi khususnya dalam perkembangan komputer, komputer ini tidak lain berperan dalam menciptakan arsip dan menyimpan arsip. Oleh karena itu, arsip juga mengalami perkembangan baik itu dari bentuknya yaitu dalam bentuk elektronik yang dihasilkan lansung dari komputer maupun cara mengelolanya didalam sebuah komputer. Arsip yang dihasilkan langsung dari komputer dan/atau arsip tekstual/konvensional yang dikonversikan kedalam bentuk digital (berupa scan) dinamakan dengan arsip elektronik.

Arsip elektronik adalah arsip yang lahir dari perkembangan teknologi khususnya teknologi komputer. Pada dasarnya arsip elektronik merupakan informasi yang direkam dan disimpan dalam media elektronik dengan wujud digital. Hal utama yang perlu diperhatikan dalam pengelolaan arsip elektronik adalah kecepatan dan ketepatan dalam penemuan kembali arsip atau informasi (Sugiarto dan Wahyono: 2014). Oleh karena itu, saat ini arsip elektronik menjadi kebutuhan di berbagai organisasi mengingat keefektifan dalam pengelolaannya. 
Arsip elektronik sangat dibutuhkan dizaman sekarang khusunya di Indonesia. Mengingat letak Indonesia berada diantara 2 lempeng bumi yang menyebabkan sering terjadinya bencana di tanah Indonesia seperti gempa bumi, tsunami, gunung meletus, banjir, dsb. Oleh karena itu pengelolaan arsip secara elektronik lebih efisien dibanding secara manual, karena jika secara manual, saat terjadi bencana alam resiko yang dihadapi akan lebih besar, perbaikan yang susah dan memakan waktu yang lama dan pastinya biaya yang tidak sedikit untuk memulihkan kembali arsip - arsip yang telah rusak.

Tetapi apakah semua organisasi, lembaga pemerintahan, perusahaan, bahkan pendidikan telah menerapkan arsip elektronik dan sudah melakukan pengelolaan arsip secara elektronik. Apakah lembaga pendidikan yang dalam kegiatan sehari - harinya pasti ada surat masuk, surat keluar, surat izin pendirian sekolah, data siswa/siswi, data guru, dsb sudah dilakukan secara elektronik oleh pihak sekolah. Apakah arsip sudah dikelola oleh seseorang yang ahli di bidang kearsipan atau dinamakan Arsiparis? Atau kah masih dikelola oleh guru bidang ajar atau pihak Tata Usaha?

Kegiatan pengelolaan arsip sangat penting dilakukan demi keberlangsungan kegiatan sekolah, karena arsip merupakan bukti atau rekaman dari adanya sebuah kegiatan. Oleh karena itu pembahasan mengenai hal ini perlu untuk dibahas lebih lanjut.

Seperti halnya di MTS Aulia Cendikia terlihat bahwa arsip yang berbentuk tekstual yang dikelola secara manual terlihat cukup banyak dan tersusun dilemari, namun saat proses temu kembalinya masih sulit dilakukan karena harus membongkar satu persatu. Sedangkan, untuk arsip yang elektronik terlihat bahwa pihak pengelola arsip sering mendapatkan kendala dalam mengakses sistem manajemen arsip berbasis elektronik, hal ini karenakan gangguan dari jaringan.

Dari penjelasan tersebut, maka penulis tertarik melakukan penelitian dengan tema "Sistem Manajemen Arsip di MTS Aulia Cendikia" terutama dalam hal pengelolaan arsip baik manual dan elektronik, media penyimpanan arsip baik manual maupun elektronik, dan temu kembali arsip.

Dari latar belakang diatas, dapat diketahui bahwa cakupan permasalahan yang akan dibahas dalam makalah ini adalah :

1. Bagaimana pengelolaan arsip di MTS Aulia Cendikia ?

2. Bagaimana media penyimpanan arsip di MTS Aulia Cendikia?

3. Bagaimana cara temu kembali arsip di MTS Aulia Cendikia?

\section{METODE PENELITIAN}

Penelitian ini menggunakan metode penelitian kualitatif deskriptif. Metode penelitian kualitatif melibatkan upaya upaya penting, seperti mengajukan pertanyaan - pertanyaan dan prosedur prosedur, mengumpulkan data yang spesifik dari para partisipan, menganalisa data, dan menafsirkan makna data (Adib: 2016). Metode penelitian deskriptif bertujuan untuk membuat deskripsi atau gambaran secara sistematis, faktual, dan akurat mengenai fakta - fakta, sifat - sifat hubungan antar fenomena yang diselidiki. Teknik pengumpulan data dilakukan dengan observasi mengamati langsung dan wawancara kepada Kepala Tata Usaha MTS Aulia Cendikia. Wawancara merupakan salah satu metode pengumpulan data dengan jalan komunikasi, yakni melalui kontak atau hubungan pribadi antara pengumpul data (pewawancara) dengan sumber data (responden) (Adi: 2016). Wawancara yang dilakukan dalam penelitian ini yaitu secara langsung (face-to-face) berhadapan dengan responden untuk menanyakan secara lisan hal - hal yang diinginkan, dan jawaban responden dicatat oleh pewawancara. 


\section{HASIL DAN PEMBAHASAN}

\section{Pengertian Arsip}

Arsip berasal dari kata Belanda yaitu archief yang bersumber pada kata Yunani archeion artinya gedung kota, kuno atau archivum (bahasa Latin), artinya gedung. Dari kata archivum muncullah kata archives (bahasa Inggris), archivio (Italia), archief (Belanda), archiv (Jerman), dan arsip (Indonesia). Di Indonesia sendiri, ada istilah lain yaitu kintaka yang berarti surat dan banyak digunakan pada tahun 1950-an. Selain itu juga ada istilah warkat yang artinya surat (Basuki: 2015).

Didalam Undang - Undang Dasar Republik Indonesia No. 7 Tahun 1971 telah disebutkan pengertian arsip. Namun perlu disesuaikan dengan perkembangan dan kebutuhan kehidupan bermasyarakat, berbangsa, dan bernegara yang dipengaruhi oleh perkembangan tantangan nasional dan global serta perkembangan teknologi informasi dan komunikasi.

Maka dibentuklah Undang - Undang Republik Indonesia No. 43 Tahun 2009 tentang Kearsipan. Dalam Pasal 1 ayat (2) menyebutkan bahwa Arsip adalah rekaman kegiatan atau peristiwa dalam berbagai bentuk dan media sesuai dengan perkembangan teknologi informasi dan komunikasi yang dibuat dan diterima oleh lembaga negara, pemerintahan daerah, lembaga pendidikan, perusahaan, organisasi politik, organisasi kemasyarakatan, dan perseorangan dalam pelaksanaan kehidupan bermasyarakat, berbangsa, dan bernegara.

Dapat ditarik satu hal dari pengertian menurut Undang - Undang diatas, yaitu "perkembangan teknologi informasi dan komunikasi". Artinya arsip mengalami perkembangan baik dalam bentuk fisik maupun media penyimpanannya seiring dengan perkembangan teknologi. Alhasil muncullah yang dinamakan dengan arsip elektronik.
Dalam National Archives of Australia, arsip elektronik adalah arsip yang diciptakan, dikomunikasikan dan disimpan dengan menggunakan teknologi komputer. Arsip elektronik dapat diciptakan langsung dengan menggunakan teknologi komputer atau dapat juga dalam bentuk yang telah dikonversikan ke format digital dari format aslinya (misalnya hasil scan terhadap dokumen kertas). (Digital records are records created, communicated and maintained by means of computer technology. They may be 'born digital' (created using computer technology). Or they may have been converted into digital form from their original format (eg scans of paper documents)) (National Archives of Australia: 2013).

Menurut NASA (National Archives and Record Administration), arsip elektronik adalah arsip yang disimpan dan diolah dalam satu format dimana hanya mesin komputer yang dapat memprosesnya (means any information that is recorded in a form that only a computer can process) (National Archives of Australia: 2017). Arsip juga dianggap sebagai "memori organisasi"; "bahan baku untuk pembuatan keputusan"; dan "dasar untuk pertanggungan hukum" (Yusof dan Chell: 1988).

Dapat disimpulkan bahwa arsip merupakan bukti atau rekaman dari adanya kegiatan dalam sebuah organisasi, lembaga, instansi, perusahaan, $\mathrm{dsb}$ yang harus dikelola sedemikian rupa demi berjalannya sebuah organisasi. Arsip perlu dikelola dengan baik karena jika tidak dikelola maka akan berisiko terhadap keberlangsungan hidup sebuah organisasi, lembaga, instansi, perusahaan, dsb. Akibat dari perkembangan teknologi, muncullah arsip elektronik dimana arsip elektronik ini dapat diciptakan langsung dari komputer dan/atau hasil konversi dari arsip tekstual. Arsip elektronik hanya dapat dikelola dan dibaca oleh 
mesin komputer.

\section{Pengelolaan Arsip di MTS Aulia Cendikia}

Dalam

proses

pengelolaan dokumen, kegiatan yang paling memerlukan perhatian yang besar yakni kegiatan penataan (filling) dan pengamanan arsip, dimana jika kegiatan ini tidak dilakukan dengan baik dan benar, maka akan menghambat proses penemuan kembali arsip jika dibutuhkan. Penataan serta penyimpanan arsip adalah pengaturan secara sistematis keseluruhan data atau permasalahan sedemikian rupa sehingga apabila sewaktu-waktu dibutuhkan dapat segera ditemukan kembali. Namun arsip akan terus bertambah setiap harinya.

Dengan semakin berkembangnya aktifitas suatu organisasi maka berkembang pula jumlah berkas yang ada dalam instansi - instansi tersebut. Berkas - berkas tersebut yang dikenal dengan dokumen atau arsip. Perkembangan arsip akan sebanding dengan pertumbuhan jumlah pekerjaan tulis - menulis yang terjadi di kantor dan sebanyak itu pula yang ditimbulkan akibat kelahiran dokumen (Sugiarto dan Wahyono: 2014). Oleh karena itu, dibutuhkan sebuah pengelolaan arsip atau dengan nama lain Manajemen Kearsipan (Record Management).

Pengelolaan arsip atau Manajemen Kearsipan (Record Management) adalah seni pengendalian dokumen berupa pengendalian penggunaannya, pemeliharaan, pelindungan, serta penyimpanan arsip. Ricks, Swafford dan Gow mengatakan bahwa records managementadalah " $a$ function that provides for the systematic control of records from creation, or receipt, through their processing, distribution, organisation, storage and retrieve to their ultimate disposition" (Yusof dan Chell: 2017). Maksudnya, manajemen arsip adalah fungsi yang menyediakan kontrol sistematis atas arsipdari pembuatan, atau penerimaan melalui pemrosesan, distribusi, organisasi, penyimpanan dan pengambilan kembali arsip untuk disposisi akhir mereka.

Berdasarkan data yang kami peroleh dari hasil wawancara kepada Ibu Lastri (KA Tata Usaha) di MTS Aulia Cendikia, pengelolaan arsip nya ada yang masih secara manual dan ada sebagian yang sudah elektronik. Arsip tekstual seperti surat masuk dan surat keluar masih dikelola secara manual. Surat surat yang masuk akan di catat nomor suratnya di buku khusus, lalu disimpan di rak yang sesuai dengan isi arsip. Sebagian juga ada yang di fotokopi terlebih dahulu. Untuk surat keluar, ada yang diarsipkan atau disimpan di rak. Intinya setiap arsip tekstual akan dikelola secara manual.

Selain itu ada juga pengelolaan arsip secara elektronik. Misalnya daftar absen siswa masih di simpan di laptop (bentuk tekstualnya disimpan di rak). Absen guru bagi yang sudah PNS menggunakan finger print untuk pendataan di Kementrian Agama. Untuk arsip asli dari komputer (diketik di word atau excel) masih disimpan di laptop khusus sekolah dan back up nya ada di Hard disk yang setiap 2 minggu nya akan diperbarui.
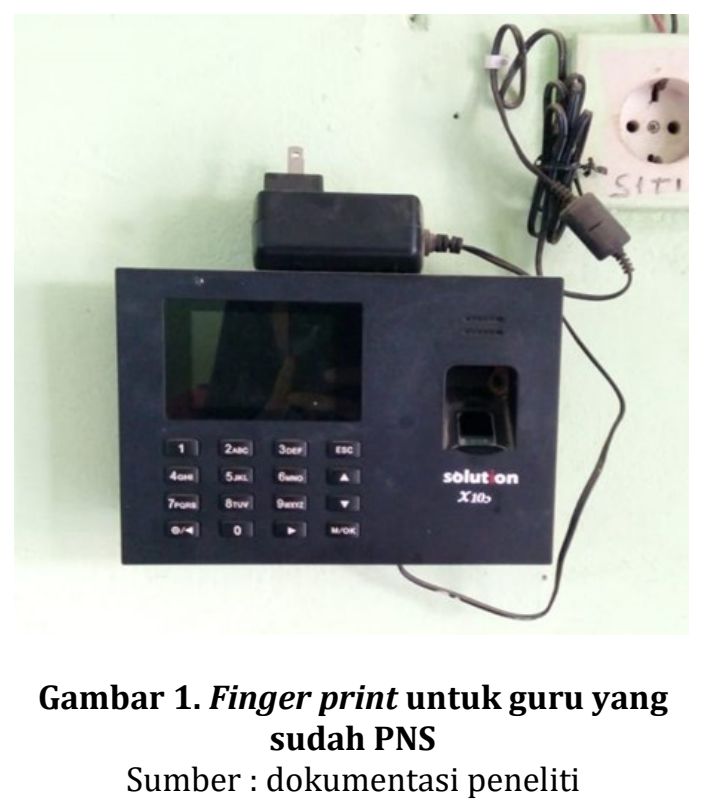
Menurut ibu Lastri, pengelolaan arsip baik itu manual maupun elektronik sangatlah penting karena arsip digunakan sebagai "memori" atau ingatan akan adanya kegiatan di sekolah. Jika saat digunakan untuk akreditasi, maka arsip arsip inilah yang akan digunakan untuk akreditasi sekolah.

Berdasarkan hasil observasi dan wawancara tersebut penulis menyimpulkan bahwa di Mts Aulia Cendikia ini untuk pengelolaan arsipnya belum cukup maksimal dalam hal penataan, karena arsip yang berbentuk tekstual dalam pengelolaannya masih sebatas pengelompokkan umum, belum yang mendetail. Sehingga hal ini menyebabkan perlunya waktu yang cukup lama dalam proses temu kembali informasi.

\section{Media Penyimpanan Arsip di MTS Aulia Cendikia Palembang}

Setelah arsip - arsip tersebut dikelola, maka hal yang terpenting selanjutnya adalah menyimpan arsip tersebut jika sudah tidak digunakan secara terus - menerus. Didalam kehidupan dunia pendidikan tentunya banyak sekali dokumen-dokumen yang dihasilkan dari lembaga pendidikan tersebut. Dokumen itu sebagai bukti bahwa adanya kegiatan di dalam sebuah lembaga atau yayasan, serta sebagai bukti fisik bahwa lembaga pendidikan aktif dan suatu kegiatan. Dengan begitu maka pada waktunya pasti arsip akan terus bertambah dan apabila tidak dikelola dan disimpan dengan baik dan benar tentu arsip itu akan mengalami kerusakan.

Seiring dengan perkembangan teknologi maka media penyimpanan arsip pun berkembang, tidak hanya disimpan secara manual saja, namun dapat pula disimpan secara online agar arsip tersebut menjadi sebuah arsip elektronik. Terjalannya proses pengelolaan penyimpanan arsip dengan baik dan benar ditunjang dengan pengelola arsip yang menyadari dan memahami pentingnya sebuah arsip dengan begitu dia akan memelihara dan berawat arsip sebaik mungkin.

Di Mts Aulia Cendikia Palembang banyak sekali arsip yang mereka miliki mulai dari SK Yayasan, Surat tanah, Absensi Guru, dll. Oleh karena itu mereka menyimpan arsip tersebut secara manual semi elektronik. Dikatakan demikian karena dibagian Kantor atau Tata Usaha Mts Aulia Cendikia telah menyimpan arsip-arsip tekstualnya disebuah lemari khusus dan menyimpan secara Online di aplikasi Emis. Berikut adalah penjelasan lebih detail terkait media penyimpanan arsip di Mts Aulia Cendikia Palembang.

a. Media Penyimpanan Arsip Manual

Arsip tekstual biasanya dibagi menjadi 5 jenis dan ini menimbulkan berbagai sistem yang berbeda untuk media menyimpannya. Jenis umum arsip dan sistem penyimpanan yang sering digunakan oleh beberapa lembaga atau yayasan dapat dilihat dalam table 1 (Basuki: 2015):

Dapat disimpulkan bahwa arsip tekstual yang disimpan secara manual tetap dilakukan proses pengelolaan dengan baik dan benar, terutama dalam hal media penyimpanannya. Hal ini bertujuan agar sebuah arsip yang ada dapat dengan mudah diterapkan sistem simpan temu kembali informasi.

Berdasarkan observasi dan wawancara yang dilakukan dengan ibu Lastri selaku KA TU Mts Aulia Cendikia,beliau mengatakan bahwa di Mts Aulia Cendikia ini menyimpan arisp-arsip teksual didalam beberapa lemari penyimpanan yang disediakan. Serta penyimpanan ini pun disusun berdasarkan subjek - subjek yang ada pada arsip di Mts tersebut. Ibu Lastri mengatakan bahwa apabila terdapat surat masuk ke Mts maka dia langsung meletakkan ke tempat arsip yang sesuai dengan subjek surat tersebut kedalam rak penyimpanan arsip 
Tabel 1. jenis umum arsip dan sistem penyimpanan

\begin{tabular}{|c|c|c|}
\hline No & Jenis arsip/recod & Sistem penyimpanan \\
\hline 1 & $\begin{array}{l}\text { Korespodensi (termasuk } \\
\text { surat, memorandum, telegram, lampiran, } \\
\text { laporan dan dokumen terkait). }\end{array}$ & $\begin{array}{l}\text { Berkas subjek menurut klasifikasi, namun } \\
\text { korespondensi dapat menggunakan setiap } \\
\text { jenis sistem berkas korespodensi sering } \\
\text { disebut berkas umum untuk } \\
\text { membedakannya dari seri recod dinamis } \\
\text { lainnya. }\end{array}$ \\
\hline 2 & $\begin{array}{l}\text { Recod transaksi (formulir dan korespondensi } \\
\text { yang memberikan bukti adanya transaksi). }\end{array}$ & $\begin{array}{l}\text { Susunan alfabetis atau numerik berdasarkan } \\
\text { nama atau pengenal numerik, misalnya } \\
\text { nomor surat, nomor tagihan. Sering kali } \\
\text { jenis dokumen ini bersifat bebas dan tidak } \\
\text { dikelompokkan berdasarkan folder berkas. }\end{array}$ \\
\hline 3 & $\begin{array}{l}\text { Recod proyek (Korespondensi, nota dan data } \\
\text { lain yang terkait pada proyek tertentu, } \\
\text { seperti pengembangan, sebuah produk, } \\
\text { pelaksanaan kegiatan sebuah proyek atau } \\
\text { dokumentasi sistem). }\end{array}$ & $\begin{array}{l}\text { Biasanya disimpan menurut nama proyek } \\
\text { atau nomor, sering kali dibagi lebih lanjut } \\
\text { menurut subjek dan klassifikasi }\end{array}$ \\
\hline 4 & $\begin{array}{l}\text { Berkas kasus (rekam medis dan recod } \\
\text { personal lainnya, klaim, tuntutan, hukum, } \\
\text { kontrak asuransi dan berkas sejenis. Biasanya } \\
\text { merujuk pada personel tertentu). }\end{array}$ & $\begin{array}{l}\text { Biasanya menurut nama atau nama } \\
\text { kelompok atau diindeks menurut nomor } \\
\text { berkas }\end{array}$ \\
\hline 5 & $\begin{array}{l}\text { Berkas khas (peta dan gambar rekayasa atau } \\
\text { engineering, pita atau tapes dan gulungan reel, } \\
\text { foto sinar X, foto, gambar, clipping, dan berkas } \\
\text { rujukan tercetak lainnya dan media terbacakan } \\
\text { mesin). }\end{array}$ & Biasanya nomor indeks abjad \\
\hline
\end{tabular}

Sumber : Sulistyo Basuki, 2015

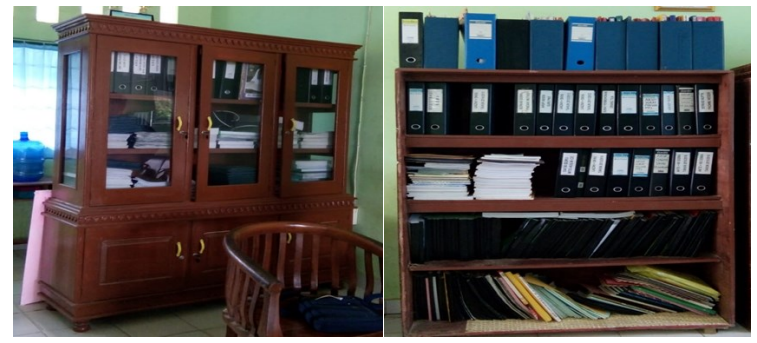

Gambar 2. Lemari Penyimpanan Arsip Tekstual

Sumber : dokumentasi peneliti

Untuk mencegah menumpuknya arsip tekstual maka pihak pengelola selalu melakukan pemusnahan arsip dalam jangka waktu 5 tahun 1 kali. Serta Untuk saat ini penyimpanan arsip tekstual di Mts Aulia Cendikia dilakukan secara kombinasi, yang dimana arsip yang menyangkut personalia misalnya absen, gaji, kredit, dll disimpan oleh masing-masing unit dan lembaga atau yayasan hanya melakukan sistem pengawasan atau kontrol keadaan. Sedangkan untuk arsip vital seperti SK lembaga atau yayasan, surat tanah dll, disimpan langsung oleh lembaga atau
yayasan.Dengan begitu maka arsip yang ada akan benar-benar tersimpan dan terjaga dengan sebaik mungkin.

bedia penyimpanan arsip
elektronik
Arsip tekstual pada dasarnya sangat rentan terhadap kerusakan yang diakibatkan adanya bencana. Oleh karena itu, metode pencegahan yang dilakukan terkait dengan sarana yang digunakan dalam menciptakan arsip elektronik. Berdasarkan media rekam yang digunakan untuk menyimpan arsip elektronik dapat dibedakan menjadi tiga bagian, yaitu yang terekam dalam media bentuk khusus, media magnetik, dan media optic (Krihanta: 2014). Ada beberapa metode proteksi arsip vital elektronik, diantaranya adalah metode rekam data yang dimana metode ini menganjurkan setiap arsip elektronik direkam pada beberapa media tertentu. Metode Microform sebagai sumber 
cadangan (Back Up Source), dan metode perlindungan file-file EDP. Dengan begitu dapat disimpulkan bahwa arsip elektronik pun harus dilakukan penyimpanan dengan baik agar arsipnya tetap tersimpan dan terjaga.

Berdasarkan hasil observasi dan wawancara langsung dengan ibu Lastri dapat diketahui bahwa Mts Aulia Cendikia sudah menggunakan sistem Emis, dimana Emis adalah Education management information System. Emis merupakan sistem informasi yang dikembangkan oleh kementrian agama untuk memudahkan input data sekolah, pondok pesantren, dan pendidikan tinggi islam. Dengan begitu maka informasi tetang lembaga atau yayasan tensimpan di aplikasi Emis tersebut. Emis sendiri sudah digunakan di Mts Aulia Cendikia sejak tahun 2016, dan selama menggunakan Emis pihak pengelola sering mengalami gangguan atau terkendala sinyal dijaringan dan lupa pasword Emis saat terjadinya pertukaran pengelola Emis. Selain semua data sekolah berbentuk elektronik disimpan di Emis, pihak yayasan juga menduplikasi di 1 leptop khusus dan 1 hardisk khusus dimana setiap 2 minggu sekali dilakukan pembaharuan, baik tentang isi arsip yang bertambah ataupun mengecek apakah tempat penyimpanan terkena virus atau tidak.

Selain Emis, Mts Aulia Cendikia juga masuk didalam aplikasi online Bos Pintar. Dimana dalam hal ini sekolah yang masuk di aplikasi Bos Pintar adalah sekolah yang terdapat siswanya menerima beasiswa Bos Pintar, maka di aplikasi tersebut akan tercatat data sekolah dan siswa yang menerima beasiswa tersebut. Data tersebut dapat berupa nama sekolah, nama siswa, NIK, NISS, dll.

Berdasarkan pernyataan diatas penulis dapat mengambil kesimpulan bahwa pengelola arsip di Mts Aulia Cendikia sudah memahami bagaimana pentingnya arsip untuk sebuah lembaga atau yayasan, dan arsip disimpan guna untuk mengingat apa saja yang pernah dilakukan oleh Mts Aulia Cendikia serta sebagai bukti fisik dari keaktifan Mts Aulia Cendikia.

\section{Temu Kembali Arsip}

Temu kembali informasi dapat diartikan sebagai kegiatan yang bertujuan untuk menyediakan informasi kepada pengguna sebagai jawaban akan kebutuhan informasi pengguna. Sistem simpan dan temu kembali informasi atau Information Retrieval yaitu upaya membantu pengguna menemukan kembali dokumen ataupun informasi informasi yang sesuai dengan kebutuhan pengguna dari suatu kumpulan informasi secara otomatis yang terdapat di perpustakaan (Basuki: 2013).

Dalam kaitannya dengan kearsipan, temu kembali informasi diartikan sebagai sebuah proses penemuan kembali arsip yang sebelumnya telah disimpan di media penyimpanan untuk keperluan tertentu. Untuk memudahkan temu kembali arsip maka arsiparis atau staf TU melakukan sebuah metode atau cara yang dapat memudahkan penemuan arsip. Cara penemuan kembali arsip manual dengan arsip elektronik sedikit berbeda. Arsip elektronik lebih mudah untuk ditemu kembalikan karena ada sistem komputer yang memudahkannya. Untuk arsip manual, tergantung tingkat kreatifitas arsiparis dalam mengelolanya.

Berdasarkan observasi dan wawancara yang kami lakukan terhadap Ibu Lastri, beliau mengatakan bahwa di Mts Aulia Cendikia ini sistem temu kembali informasi nya ialah dengan dibuatkan lebel nama di setiap rak penyimpanan, dan setiap rak dikelompokkan berdasarkan isi dan rak. Gunanya untuk mempermudah temu kembali informasi, contohnya, "standar isi", "Standar Kompetensi Lulusan", "Standar Proses", "Standar Tenaga Pendidik dan Kependidikan", "Standar Sarana dan Prasarana", "Standar Pembiayaan", dsb. 


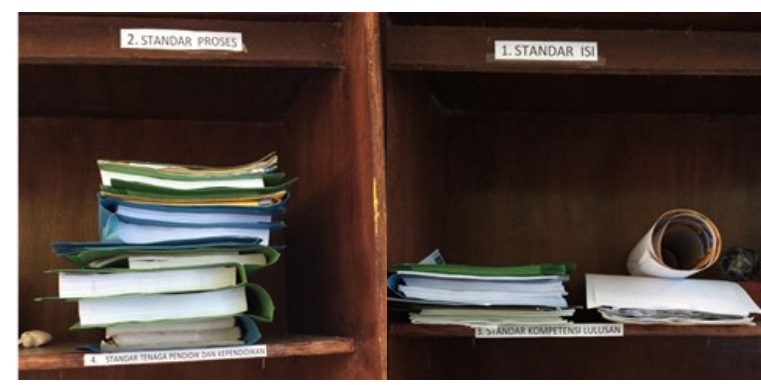

Gambar 3. Contoh label nama pada rak penyimpanan arsip Sumber : dokumentasi peneliti

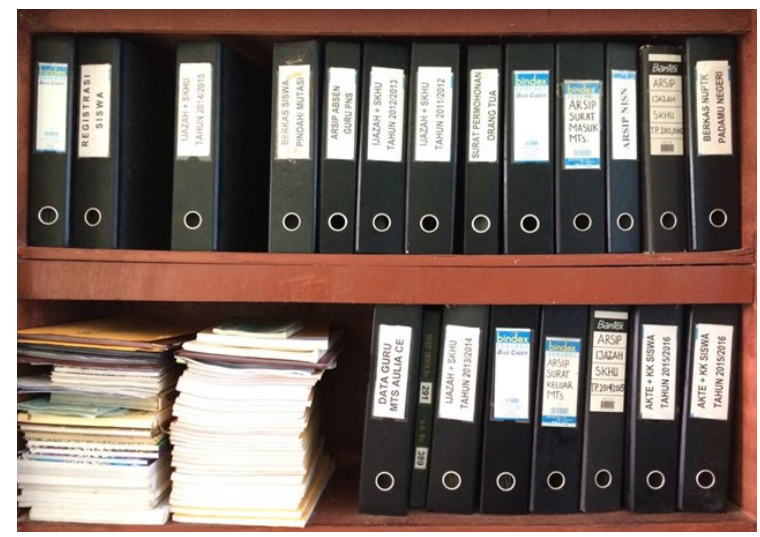

Gambar 4. Contoh label nama pada penyimpanan arsip (ordner bantex) Sumber : dokumentasi peneliti

Label nama tersebut memudahkan pengguna menemukan kembali arsip yang diinginkannya. Didalam kegiatan kearsipan temu kembali informasi biasanya untuk dokumen yang di ketahui atau untuk informasi mengenai subjek tertentu, file biasanya berupa katalog atau indeks atau penyimpanan informasi berbasis komputer. Biasanya penemuan kembali arsip bias dengan manual (untuk arsip tekstual atau konvensional) maupun menggunakan komputer (untuk arsip elektronik).

Walaupun sudah di beri label nama pada rak maupun pada order bantex, temu kembali arsip masih memerlukan waktu yang lama. Dikarenakan berkas atau arsip yang ada di dalam rak maupun order bantex belum tersusun rapi berdasarkan tanggal. Sehingga saat menelusur arsip masih perlu diperiksa satu per satu dan itu tidakla efektif.

Seharusnya dalam pengelolaan arsip yang baik yaitu pada saat temu kembali arsip nya harus cepat, tepat, dan akurat. Misalnya dengan menyusun ulang arsip berdasarkan tanggal pembuatannya, tanggal masuk, ataupun tanggal keluar.

\section{KESIMPULAN}

Dari pembahasan diatas dapat disimpulkan bahwa Kepala Tata Usaha MTS Aulia Cendikia mengelola arsip secara manual dan elektronik. Arsip tekstual seperti surat masuk dan surat keluar masih dikelola secara manual, sedangkan untuk arsip elektronik seperti teks yang ditulis di word masih dikelola didalam komputer. Media penyimpanan arsip manual yaitu disediakan rak khusus penyimpanan arsip, sedangkan arsip elektronik seperti data siswa disimpan di media online yaitu EMIS (Education management information System). Untuk temu kembali arsip, dilakukan dengan cara pemberian label nama disetiap rak, sesuai dengan isi dari arsip tersebut.

Pentingnya pengelolaan arsip harus disadari oleh setiap pengelola lembaga pendidikan. Dalam hal ini saran kami kepada pihak sekolah untuk lebih memperhatikan pengelolaan arsipnya. Seperti kebersihan atau perawatan arsip, temu kembali arsip yang bisa dibuat lebih efektif, dan mulai memfokuskan pada pengelolaan secara elektronik.

\section{DAFTAR PUSTAKA}

Rianto, Adi. (2004). Metodologi Penelitian Sosial dan Hukum. Jakarta: Granit.

Basuki, Sulistyo. (2015). Pengantar Ilmu Kearsipan. Jakarta: Universitas Terbuka.

---. (2013). Pengantar Ilmu Perpustakaan. Tangerang Selatan: Universitas Terbuka.

Krihanta. (2014). Pengelolaan Arsip Vital. Tangerang Selatan: Universitas Terbuka. 
Rustam, Muhammad. (2014). Pengelolaan Arsip Elektronik. Tangerang Selatan: Universitas Terbuka.

Sugiarto, Agus, dan Teguh Wahyono.. (2014). Manajemen Kearsipan Elektronik. Yogyakarta: Gava Media.

M. Yusof, Zawiyah, dan Robert W. Chell. (1998). The eluding definitions of records and records management: is a universally acceptable definition possible? Part 1. Defining the record. Records Management Journal, 2.

---. (1999). The eluding definitions of records and records management: is a universally acceptable definition possible? Part 2: Defining records management. Records Management Journal, 9.

Utami, Rahayu Tri. ---. Sistem Pengelolaan Arsip Dinamis Manual (Fisik) Pada Politeknik LP3i Jakarta Kampus Cimone. Jurnal Lentera Bisnis, 2.

National Archives and Records Administration. Context for Electronic Records Management [ERM]. (2017). https://www.archives.gov/recordsmgmt/initiatives/context-for-erm.html. --

---. What's an Archives?. (2016). https://www.archives.gov/about/info/ whats-an-archives.html. --- 